ROCZNIKI PEDAGOGICZNE

Tom 12(48), numer $1-2020$

DOI: http://dx.doi.org/10.18290/rped20121-6

\title{
MAN'S EDUCATION IN THE PERSPECTIVE OF PERSONALISTIC PHILOSOPHICAL ANTHROPOLOGY AND REALISTIC PEDAGOGY OF FR. JACEK WORONIECKI
}

\section{INTRODUCTION}

Fr. Jacek Woroniecki, Dominican friar, outstanding theologian, philosopher and pedagogue, was both a theoretician and practician, and "on the basis of his own work, he tried to show that theory may be accompanied by application. He understood very well the Latin saying: Verba movent-exempla trahunt, and he applied it in his own life" (Miławicki, 2017, p. 83). Among many different activities he took up, the issue of upbringing and education was very important. He emphasized the significance of education in human life, and he perceived pedagogy as an integral part of ethics. According to Jerzy Gałkowski, "this statement, as well as the whole of ethics, is based on the dynamic approach to the human being and human nature" (Gałkowski J., 2000, p. 83). One has to note that the concept of education and pedagogy of Fr. Jacek Woroniecki "is based on the existential and epistemological realism, as it proclaims the necessity of an integral and universal education of a man. That is why, pedagogy cannot be separated from philosophical anthropology and ethics, which provide the image of what the man is, what moral good is, and, as a consequence, they outline the objective of pedagogy" (Krasnodębski, 2009, p. 36). Since this concept refers to existential and cognitive realism, we may say that such approach is still valid.

Dr. Marzena Chrost - Department of General Pedagogy and Theory of Education, Institute of Educational Sciences, Faculty of Pedagogy, Jesuit University Ignatianum in Krakow; correspondence address: ul. Kopernika 26, 31-501 Kraków; e-mail: marzena.chrost@ignatianum.edu.pl; ORCID: https://orcid.org/0000-0003-3309-6574. 
Therefore, the objective of this article is showing the theory of educating a person in the perspective of personalism, and outlining the concept of realistic pedagogy of Fr. Jacek Woroniecki. Taking into account the complexity of this issue, only its selected aspects shall be discussed. First of all, I shall present the anthropological foundation for education, with special emphasis on universalism and pedagogical realism. Then, I shall present how Fr. Jacek Woroniecki understood and defined education, and I shall discuss his concept of the man's development-from personality to the personalence. ${ }^{1}$ Also, I shall present selected actions that may be applied in the process of education to help the person aim at and achieve perfection.

\section{ANTHROPOLOGICAL FOUNDATION FOR EDUCATION}

While presenting the anthropological assumptions of the theory of education and pedagogy, which was suggested by Fr. Jacek Woroniecki, one should refer to the classical Greek thought and Christian universalism. It has to be mentioned that such a theory is not only rooted "in the classical paideia, but especially in anthropology and in the ethics of Aristotle and St. Thomas Aquinas, as well as in the patristic and scholastic tradition (Cajetan, F. Suarez), and in the authority of the Holy Scriptures themselves. Thus, his paideia created an «eternal» theory of education-paedagogia perennis" (Krasnodębski, 2009, p. 31). This concept is characterised by universalism and pedagogical realism.

\section{PEDAGOGICAL UNIVERSALISM}

Referring to the ontological universalism in upbringing, one should assume that the subject of human cognition is reality in all its scope. And the basis for knowledge and behaviour includes the most general principles of being and acting, such as the principle of identity, consistency, causality,

\footnotetext{
${ }^{1}$ Using this term I follow the practice of translation of the Polish word "osobistość" into English as "personalence." Personalence is one of the key concepts in Woroniecki's writings. The Authors of published recently monograph on Fr. Woroniecki's life and work describe this term as follow: "It is understood by him as perfection, to which the development of human personality should ultimately lead, on account of its personal status and rational nature. Personalence demonstrates how a particular person should behave and act with a sense of responsibility for oneself' (Mazur, Kiereś, Skrzyniarz, Płazińska, 2019, p. 18).
} 
purposefulness, and the principle than one should do good and avoid what is evil.

Three main constituents may be distinguished in the discussion on the pedagogical universalism: the scope of the subject of pedagogy, its objective aim and formal reason for the object (cf. Chłodna, 2007, p. 129-130; Śleziński, 2016, p. 184). As for the scope of the subject of pedagogy, universalism shall include multifaceted perception of education itself and all the factors that condition and influence education. That is why, Fr. Jacek Woroniecki wanted education to be common and available to everyone. However, taking into account the scope of the subject of educational work, universalism requires multifaceted educational influence which shall refer to the whole personality of a man (cf. Chłodna, 2007, p. 129). Thus, taking into account the man's developmental possibilities, Fr. Jacek Woroniecki emphasized human potentiality and "plasticity" (cf. Woroniecki, 1986, p. 330, 331). Indubitably, one has to admit that the potentiality included in human nature is an important element of the educational process, as it may be practiced, developed, shaped and perfected.

As for the objective aim, it is assumed that all the educational factors and values are subject to the man's moral culture in accordance with his final goal. Therefore, in his theory, Fr. Jacek Woroniecki emphasised the central role of moral education, "which enlightens all the parts of ethics and constitutes one of the most precious tests of the moral value of all other ethical theories" (Woroniecki, 1986, p. 31). Taking into account the objective aim of pedagogy, universalism shall be expressed in going towards the real and most general objective in a way that makes it possible to take into account and apply all the factors necessary in the process of education.

It should also be emphasized that Fr. Jacek Woroniecki paid attention to the meaning of the objective in the work of a pedagogue, as not only does the aim determine the means and ways of achieving it, but it also specifies the very nature of the activities or skills (cf. Woroniecki, 1986, p. 64). Also, he separated the objective of the science on education (pedagogics) from the objective of the education itself (pedagogy). The objective of pedagogics is the knowledge of how we should educate children and why we should do so. Pedagogy, which refers to a specific application of pedagogics in action, may be a currently practical knowledge due to its aim (cf. Chłodna, 2007, p. 130).

The next factor of pedagogical universalism is the formal reason for the subject of pedagogy. "It includes the principles on the basis of which such science justifies its characteristic statements. In this case, pedagogical 
universalism means adopting such, most general principles of thinking and acting as the basis for the theory and practice of education, that would make it possible to improve different aspects of human personality in accordance with its final objective" (Chłodna, 2007, p. 130).

Also, one should note that as for the theoretical reflection, according to Fr. Jacek Woroniecki, pedagogy should be based on the Aristotle's concept of the four causes (reasons): material, formal, efficient and final (cf. Ga1kowski S., 1998, p. 33; Śleziński, 2016, p. 184; Mazur, Kiereś, Skrzyniarz, Płazińska, 2019, p. 68). Therefore, one has to distinguish the subject, object and the reason for education. The subject of education is the man, i.e. the material and-partially-efficient reason for the educational practice. The object of education, the objective and formal reason, is all that is to be produced (updated) within the man due to the educational activity. The two causative reasons which direct the process of human education is the educator, as a specific person, and the so-called social educator (cf. Szydłowski, 2005, p. 212-213; Mazur, Kiereś, Skrzyniarz, Płazińska, 2019, p. 68).

To sum it up, we have to admit that Fr. Jacek Woroniecki's pedagogical universalism is transcendent, common, open and critical.

\section{PEDAGOGICAL REALISM}

The human problem is raised and solved within two contradictory philosophical traditions: idealism and realism. "Realism ascertains that the object of cognition and the criterion for evaluating its truth value is the perceived, autonomously existing world of things and persons" (Mazur, Kiereś, Skrzyniarz, Płazińska, 2019, p. 65). Pedagogy, which refers to the issues of metaphysics, does not mistake beings for products, relations or secondary features, which function in culture, but it becomes a realistic science. Therefore, in realistic pedagogy education should be based on the nature of being. Also, it is emphasized that it is the person who educates, and not ideas or values. At the same time, we should take into account that the man lives in a specific time and place, which is why Fr. Jacek Woroniecki claims that educational activity should be based "not only on philosophical principles; yes, strong rational basis is crucial here, but it is important not to derive them from abstract philosophical systems which sometimes do not match the reality, but to look for them, first of all, in real life. Our guides in this work may only be those thinkers whose eyes were wide open to the surrounding 
world; who derived their system not from themselves, but from deeply analysed experience of both the past generations and their own life" (Woroniecki, 2008, p. 61). It should be noted that realism refers to the real world and the real man, and it enables objective cognition of the reality. It does not allow one to fall into illusions, common schemes, ideas, stereotypes, or the virtual world of appearances.

Therefore, according to Janina Kostkiewicz, the option of pedagogical realism adopted by Fr. Jacek Woroniecki "forces one to keep constant contact with the reality of the world which is inexhaustible for the human mind" (Kostkiewicz, 2013, p. 104). Also, there is no doubt that education rooted in realism has a personal nature and aims at making the person more and more human. It is because realism requires constant improvement, self-education, incessant self-perfection and unceasing formation. In the process of education, it requires facing a specific, complex reality which is created by the educational relation: student-educator-educational situation. Each of those elements is important and cannot be neglected in the process.

\section{EDUCATION ACCORDING TO FR. JACEK WORONIECKI}

While discussing the issue of the man's education, we should present how Fr. Jacek Wroniecki perceived this phenomenon. He says: "If we want to express, in the simplest and most understandable words, what education is, we would have to say that it is getting used to or becoming accustomed to good" (Woroniecki, 1961, p. 33). Thus, we have to emphasize that-in this approach-education is focused on the fulfilment, i.e. doing good. Since, in the personalistic perspective, the objective of all actions that are taken up is the man and his actual good, as Barbara Kiereś says: "education must be based on the theory of good, showing its different kinds and their hierarchy, as only in the light of such a theory one may recognise what is valuable (precious) in the process of education" (Kiereś, 2010, p. 95).

Also, it should be noted that definitions referring to education are based on a certain adopted vision of a person, their behaviour and axiology. Personalism of the tradition of philosophical realism is "the theory of a man that recognised that the person transcends the world of nature; that, what makes the man different is personal life; and that the man is a potentialised (nonready) being, which is why he must be educated" (Kiereś, 2010, p. 91). Described in that way status of human nature results in the necessity to educate 
the person. The essence of this process is the fulfilment of humanity in the man. Thus, the objective and meaning of this process is perfecting the man. That is why Fr. Jacek Woroniecki explains that "personalistic education means that a human being, i.e. an individual, who is unaware of their objectives and tasks, should be transformed into an independent personalence who is able to use all their skills properly and consciously" (Woroniecki, 1986, p. 384). Indubitably, we should also claim that the achievement of perfection should be the objective of each human being, as all of us are called to holiness.

While discussing human education, one should also pay attention to the two levels at which the man's psyche functions: sensual and mental. Sensitive powers are related to physiological functioning, and the scope of mental abilities reaches above the senses. At those levels we may distinguish two main functions: a cognitive and appetitive one. In this context, we should note that education includes the whole human being, which is why Fr. Jacek Woroniecki also pays attention to the education of will, feelings and reason. He says: "Education is, first of all, focused on the cognitive powers, i.e. on the will and feelings, and it is to them that education is to give different internal abilities for actions called virtues. Also, it deals with the activity of the mind, but not its purely cognitive functions, but those with which the mind directs actions and which, due to this fact, are strictly related to the functioning of cognitive powers of the will and feelings" (Woroniecki, 1986, p. 344).

Within the personalistic perspective, a man is treated like a personal being whose important features include subjectivity, freedom and dignity. That is why, we can definitely state that in the process of education "all the levels of life and all the powers that the human being makes use of in his or her life in such a way that human performance becomes ever more free and independent from external as well as internal determinants as well as assumed the trait of stability to an ever greater extent, and thus were in accordance with human nature and the ultimate purpose of human life" (Mazur, Kiereś, Skrzyniarz, Płazińska, 2019, p. 69).

Moreover, Fr. Jacek Woroniecki indicates the essence of understanding the ideal of education - he believes it includes direction signs which "only show the way leading to the destination, but they are not a cause for action themselves and they do not provide an impulse for action. Direction signs are meaningless for a person who has not got any goal, who does not desire and love a goal, and who does not decide to achieve a goal. Talking to such a person about ideals is like threshing empty straw" (Woroniecki, 1986, p. 65). Thus, the man's decision concerning individual development and its 
fulfilment is very important, because it is in specific action that the man's human nature is revealed.

\section{HUMAN DEVELOPMENT_FROM PERSONALITY TO PERSONALENCE}

Fr. Jacek Woroniecki presents a dynamic vision of a person. "He shows that the basic task and fate of a human being is to create himself" (Gakkowski J., 2000, p. 97). Since human nature is not static, but it constantly develops, "its characteristic and important feature is dynamism which not only includes eliciting acts from oneself, but also development, transgression of the current status, aiming at 'being more', achieving perfection, upgrading the potentiality included in oneself" (Gałkowski J., 2000, p. 84). Thus, a man constantly develops and shapes himself as a human being, makes himself better, and this process takes the whole lifetime.

The man may get improved due to potentiality, separateness and objectivity. Potentiality, which is inscribed in human nature, is very important in the process of education. It is reflected in the need to improve all functions of living and in their diversity based on materiality or spirituality. Separateness takes into account human superiority over other creatures, the man's uniqueness and individuality both in the physical and spiritual sphere. Objectivity includes the establishment of an objective, final and superior goal of human action (cf. Michałowski, 2000, p. 154). Each person should have a "personal objective which is the development of one's personalence and the achievement of eternal life" (Niedziela, 2002, p. 188). There is no doubt that this process is long and dependent on a person.

In order to fully understand our subject, it is also important to present how Fr. Jacek Woroniecki perceived the development of personality. He claims that "the whole issue of personalistic education is included in the question: how to turn a personality into a personalence?" (Woroniecki, 1961, p. 62). Human development takes a lifetime, which is why Fr. Jacek Woroniecki states that "personality, which is given to the man at the moment his soul is created, should gradually develop into a personalence" (Woroniecki, 1961, p. 77). That is why, in the process of human development, maturation to the personalence is important, as the author claims that "dealing with the man's personality is not enough; we should get to know what is to grow and flourish out of it, i.e. a personalence who is aware of oneself, of their objectives and tasks" (Woroniecki, 1961, p. 59). Nevertheless, shaping the 
personalence is not enough - we should enjoy having it, but we also have to make it strong and brave (cf. Woroniecki, 1961, p. 61). Such transition from the personality to the personalence shows the dynamics of personalistic education and the possibility of human development. Also, it is an important challenge for taking up individual work on one's development and for the fulfilment of the process of education and self-education.

Also, Fr. Jacek Woroniecki pays attention to the influence of a personalence on other people and on the social environment as a whole. He claims that "a strong personalence creatively influences shaping other personalence in his/her closer or further environment, and it is the most precious educational leaven, which is able to transform the society's customs, taking them up to a higher level" (Woroniecki, 1961, p. 91). Such development, from the personality to the personalence, may be specified as shaping the person's character, which "may empower them both to give themselves to the service of the society, and not to allow the society to overwhelm and destroy them" (Woroniecki, 1986, p. 384).

According to Jacek Woroniecki, the development of a personalence is influenced by two more factors: "society which surrounds them and God, who gave them personality as a starting point and who waits for them to come back to Him as well-crystallised Personalences" (Woroniecki, 1961, p. 77).

Also, it is important to pay attention to the spirituals aspect of human development. There is no doubt that it is easier to notice the statics and dynamics in the person's external, rather than internal development. Watching internal changes and improvement of one's spirituality requires introspection, concentration and the ability to analyse one's own and other people's experiences. Fr. Jacek Woroniecki clearly indicates that "The prototype of a human personalence shall always be the personalence of Christ, which is covered-as for its internal essence-with the mystery of faith" (Woroniecki 1961, p. 91). And the man's objective, “towards which he should go for all his life, is returning to God from whom he came out and to whom the man is to come back in the end" (Woroniecki, 1961, p. 87).

Each person is responsible for himself, for shaping his personalence, and nobody can replace him in this task. Each of us makes the decision whether and how we wish to develop. Thus, one may distinguish three options: the lack of the direction of development, the choice aimed at the sensual or mental-but not divine-development, and the development leading to eternal life. It should be noted that if a person does not make a choice and takes up work on his development, he risks becoming degenerate. Within the 
aspect of the universalist Christian thought, only the development that leads the man towards God is good (cf. Gajda, 2006, p. 115). Fr. Jacek Woroniecki explains it in the following manner: "God made the man to participate in His internal life, in His glory and eternal happiness, and the man should fulfil that obligation. While fulfilling it, the man shall find happiness which he constantly desires in his soul. However, such desire should not be the main reason for his return to God. Such a reason should be the very objective that God placed in front of the man: God Himself and His eternal glory" (Woroniecki, 1961, p. 87).

As Maurycy Lucjan Niedziela notices, "the full meaning of the process of developing the personality into the personalence shall be revealed in the future life" (Niedziela, 2002, p. 189). The dynamic aspect of personalism is indubitably expressed in, inter alia, the process of the man's personalence maturation. And, since "how the man's personality develops into the personalence does not depend on starting in different conditions but on the way such development is carried out" (Woroniecki, 1961, p. 69), one should conclude that the man's education includes, among other things, "the cooperation with that gradual development and managing it" (Woroniecki, 1999, p. 22). Thus, in the fulfilment of the person's developmental process, it is important to take up proper and specific educational and pedagogical steps.

\section{EDUCATIONAL ACTIONS}

Realistic pedagogy is humanistic and universal, which means that it assumes integral education and shaping of a man, and it is directed to everyone who is subject to those processes. That is why, Fr. Jacek Woroniecki "postulated the popularisation of both education and integral upbringing among all social classes" (Chłodna, 2007, p. 129), especially because of the fact that education is commonly available as everyone educates and needs education (cf. Potocki, 2000, p. 122). One should also mention that factors important in such pedagogy include the care for the man's development and moral shaping of his character's will. Also, the role of responsibility is significant as the objective of education is teaching the person responsibility for themselves, so that he/she may take up self-education in an independent manner.

Referring to the issues concerning the man, realistic pedagogy also makes it possible to separate the elements that are subject to education and 
upbringing, and it enables giving answers to the question: what can be improved, educated, brought up? According to Fr. Jacek Woroniecki, "pedagogy as a science on education should focus on its main task, which is a detailed analysis of that process of getting used to things, acquiring habits or tasks, both the positive ones (virtues) that should be developed and negative ones (faults) with which one has to fight in order to control and eliminate them" (Woroniecki, 1961, p. 34). The skills acquired in the process of education are to lead the man to independence, self-education and self-upbringing. Thus, it is important to "everyday perform activities that perfect the man from the cognitive and moral perspective" (Krasnodębski, 2009, p. 49).

Therefore, one should emphasize that the essence of the process of education is forming the skills. That is why Fr. Jacek Woroniecki paid attention to what „makes a skill so important - that it accelerates and facilitates our behaviour and, in a way, saves our living energy. A skill is a kind of a condensed or capitalised experience which gives us the ability - without hesitation and long searching - to make a resolution that, in given circumstances, is the most adequate to the objective and conditions in which it is to be fulfilled" (Woroniecki, 1961, p. 48). As Stanisław Gałkowski says, "a skill is acquired through exercises the objective of which is not making the activity mechanical, but to master lasting dispositions" (Gałkowski S., 2000, p. 111-112).

Education shall also require the acquisition of many skills of the reason and will from the man. According to the realistic theory of the person, pedagogy should specify the activities that protect and improve the intellect and will, determine the activities that help the intellect and will recognize and understand truth and good, and indicate the activities that protect the person against the influence of falsehood and evil (cf. Krasnodębski, 2006, p. 60). Thus, it is very important to practice the will and feelings which "must be exercised and shaped into certain forms in order to work properly and make the behaviour unified, stable and firm" (Potocki, 2000, p. 121).

Also, we may distinguish two tasks of education: the first-obtainment of orientation in the principles of moral behaviour, and the second-proper upbringing. "Therefore, the main task of education is getting used to behaving, in all aspects of human life, according to the requirements of morality" (Woroniecki, 1961, p. 34). Thus, in the opinion of Fr. Jacek Woroniecki, educational activities should mainly result from understanding the moral actions. In order to be a well-behaved man, one has to develop one's "internal skill due to which our behaviour not only matches the requirements of morality, but is also - to a certain degree - at least in normal living conditions, 
free from internal doubts and struggles. Proper education results in the fact that we do good easily, without long hesitation; in other words-as if automatically and with a kind of pleasure" (Woroniecki, 1961, p. 33). Education should help a person improve in the personal, individual, social and spiritual aspect. It also helps the man acquire virtues (cf. Gałkowski S., 2000, p. 110) which are one of the most important means to achieve perfection. Moreover, education provides "all the citizens with real opportunities to improve and achieve proper competences and to perfect the skills according to the individual talents and needs that remain in compliance with the good of all people" (Śleziński, 2016, p. 184).

In the personalistic perspective, a person and his life, from the conception to the moment of death, is very important. That is why, the following statement of Fr. Jacek Woroniecki is very meaningful and important: "As long as the man lives, we must not doubt in him" (Woroniecki, 1961, p. 199).

To sum it up, one should conclude that the versatility and integrity of educational actions should shape a morally good person with properly directed skills, who is able to - at any time-make good and responsible decisions in managing both themselves and other people.

\section{CONCLUSION}

Fr. Jacek Woroniecki "was able to look at life realistically and precisely, and to draw conclusions from his analyses with great accuracy" (Polak, 1999 , p. 220). The above analysis related to education and upbringing results in the conclusion that the man is definitely in the centre of this process. Therefore, in Fr. Woroniecki's publications, we may notice the care for good, dignity and salvation of a man, so that the man can achieve fullness to which he is called. It is because "shaping the whole person, a full persontheir proper education - is a good and task everyone deserves" (Gałkowski J., 2000, p. 84). Also, we have to emphasize that Fr. Jacek Woroniecki was indubitably a unique person-"he educated others by radiating his own character with which he easily won people's hearts - with the example of his life, conferences, retreats, homilies, listening to confessions, lectures and his books which he almost always dedicated to educational issues as even his studies in other fields of knowledge were to serve education" (Bednarski, 1982, p. 59). His attitude and witness of life may be a model for us, and his scientific and journalist publications - due to their substantive value and still 
valid content-should become a precious and important inspiration for pedagogues, teachers, educators and other people for whom the process of education and self-education is a significant task and challenge.

\section{BIBLIOGRAPHY}

BednARsKi, F.W. (1982). Zagadnienia pedagogiczne. London: Katolicki Ośrodek Wydawniczy Veritas.

ChŁodna, I. (2007). Uniwersalizm tomizmu a uniwersalizm etyczny i pedagogiczny Jacka Woronieckiego OP. Studia z Filozofii Polskiej, 2, 117-132.

GAJdA, A. (2006). Osobowość a osobistość w świetle myśli o. Jacka Woronieckiego. In: M. PIETRZAK (ed.), Osoba i osobowość-czynniki je kształtujące (p. 103-115). Łódź: Archidiecezjalne Wydawnictwo Łódzkie.

GAŁKOwSKI, J. (2000). Filozofia i człowiek w Katolickiej etyce wychowawczej Jacka Woronieckiego OP. In: J. GAŁKOwsKi, M.L. NiEDZIELA (ed.), Człowiek-moralność-wychowanie. Życie i myśl Jacka Woronieckiego OP (p. 81-100). Lublin: Towarzystwo Naukowe KUL.

GaŁkowski, S. (1998). Ku dobru. Aktualność filozofii wychowania Jacka Woronieckiego. Rzeszów: Wydawnictwo Wyższej Szkoły Pedagogicznej w Rzeszowie.

GAŁKowsKi, S. (2000). Nowatorskie elementy "Katolickiej etyki wychowawczej” Jacka Woronieckiego OP. In: J. GAŁKOwSKI, M.L. NIEDZIELA (ed.), Człowiek-moralność-wychowanie. Życie i myśl Jacka Woronieckiego OP (p. 101-117). Lublin: Towarzystwo Naukowe KUL.

KIEREś, B. (2010). Klasyczna myśl wychowawcza w ujęciu dominikańskich mistrzów kształcenia uniwersyteckiego: J. Woroniecki, F.W. Bednarski, M.A. Krąpiec. In: K. Braun, M. ŁoBACZ, A. RYNIO (ed.), Wczoraj, dziś i jutro pedagogiki uniwersyteckiej w świetle twórczości Stefana Kunowskiego (p. 91-101). Lublin: Wydawnictwo KUL.

KostKiewicz, J. (2013). Kierunki i koncepcje pedagogiki katolickiej w Polsce 1918-1939. Kraków: Oficyna Wydawnicza "Impuls".

KRASNODĘBSKI, M. (2006). O realistyczną filozofię wychowania. Idealizm i realizm punktem wyjścia w pedagogice. Studia Philosophiae Christianae, 42/2, 45-64.

KrasnodęBSKI, M. (2009). Pedagogika Jacka Woronieckiego i Feliksa Wojciecha Bednarskiego jako egzemplifikacja etyki tomizmu tradycyjnego. Studia Etckie, 11, 29-58.

Mazur, P.S., Kiereś, B., Skrzyniarz, R., PŁazińska, A. (2019). Jacek Woroniecki. Kraków: Wydawnictwo Naukowe Akademii Ignatianum.

MichaŁowSKI, S.C. (2000). Człowiek jako podmiot wychowania w ujęciu Jacka Woronieckiego OP. In: J. GaŁKowsKi, M.L. NiEDZIELA (ed.), Człowiek-moralność-wychowanie. Życie i myśl Jacka Woronieckiego OP (p. 153-167). Lublin: Towarzystwo Naukowe KUL.

MıŁAwICKI, M. (2017). W poszukiwaniu mistrza i autorytetu duchowego. Ojciec Jacek Woroniecki OP we wspomnieniach współbraci zakonnych, uczniów i przyjaciół. In: B. JĘDRYCHOWSKA (ed.), Wychowawca. Nauczyciel. Mistrz. O potrzebie madrości, autorytetu i cnoty (p. 61-84). Wrocław: Instytut Pedagogiki Uniwersytetu Wrocławskiego.

NiedZIELA, M.L. (2002). Szkolnictwo dominikańskie. Podstawy wychowania człowieka według o. Jacka Woronieckiego OP. In: A. BARCIAK (ed.), Kultura edukacyjna na Górnym Śląsku (p. 181-190). Katowice: Societas Scientiis Favendis Silesiae Superioris-Instytut Górnośląski. 
PolAK, R. (1999). Jacek Woroniecki-życie i twórczość naukowa. Człowiek w Kulturze, 12, 219-240.

Pотоскі, A. (2000). Problemy wychowawcze w publicystyce Jacka Woronieckiego OP. In: J. GAŁKOWSKI, M.L. NiedZIELA (ed.), Człowiek—moralność—wychowanie. Życie i myśl Jacka Woronieckiego OP (p. 119-135). Lublin: Towarzystwo Naukowe KUL.

SzYdŁowSKI, P. (2005). Teologizacja pedagogiki w twórczości Jacka Woronieckiego (1878-1949). In: B. Szostek, A.J. Norasa (ed.), Filozofia i czas przeszly. Profesorowi Czestawowi Gtombikowi w 70. Rocznice urodzin (p. 210-216). Katowice: Wydawnictwo Uniwersytetu Śląskiego.

ŚLEZIŃSKI, K. (2016). Założenia realizmu ontologicznego i aksjologicznego w koncepcji wychowania Jacka Woronieckiego. Polska Myśl Pedagogiczna, 2, 175-187.

Woroniecki, J. (1961). Wychowanie człowieka. Pisma wybrane. Kraków: Wydawnictwo Znak.

WoronieCKI, J. (1986). Katolicka etyka wychowawcza, t. 1: Etyka ogólna. Lublin: Redakcja Wydawnictw KUL.

WoronieCKI, J. (1999). Program pedagogiki katolickiej. In: A. RYNIO (ed.), Pedagogika katolicka. Zagadnienia wybrane (p. 15-36). Stalowa Wola: Wydział Nauk Społecznych KUL.

WoronieCKI, J. (2008). W szkole wychowania. Teksty wybrane. Lublin: Fundacja Servire Veritati Instytut Edukacji Narodowej.

\author{
MAN'S EDUCATION IN THE PERSPECTIVE \\ OF PERSONALISTIC PHILOSOPHICAL ANTHROPOLOGY \\ AND REALISTIC PEDAGOGY OF FR. JACEK WORONIECKI
}

SUMMARY

Fr. Jacek Woroniecki, an outstanding theologian, philosopher and pedagogue, was both a theoretician and practician. Upbringing and pedagogy were among the most important of the numerous issues he analysed. He emphasized the importance of education in human life, and he treated pedagogy as an integral part of ethics. Since Fr. Woroniecki's concept of education and pedagogy refers to existential and cognitive realism, we may say that such approach is still valid.

Therefore, the objective of this publication is showing the theory of educating a person in the perspective of personalism, and outlining the concept of realistic pedagogy of Fr. Jacek Woroniecki. Taking into account the complexity of this issue, only its selected aspects were discussed. First of all, the author presented the anthropological foundation for education, with special emphasis on universalism and pedagogical realism. Then, the author described how Fr. Jacek Woroniecki understood and defined education, and discussed his concept of the man's development-from personality to the personalence. Also, the author presented selected actions that may be applied in the process of education to help the person aim at and achieve perfection.

Key words: personalence; personality; realistic pedagogy; personalism; pedagogical universalism; education. 


\section{WYCHOWANIE CZLOWIEKA W PERSPEKTYWIE PERSONALISTYCZNEJ ANTROPOLOGII FILOZOFICZNEJ I REALISTYCZNEJ PEDAGOGIKI O. JACKA WORONIECKIEGO}

\section{STRESZCZENIE}

O. Jacek Woroniecki, wybitny teolog, filozof, pedagog był zarówno teoretykiem, jak i praktykiem. Wśród wielu kwestii, które podejmował, ważne miejsce zajmowała problematyka wychowania i pedagogiki. Akcentował znaczenie wychowania w życiu ludzkim, a pedagogikę uznawał za integralną część etyki. Koncepcja wychowania i pedagogiki o. Jacka Woronieckiego odwołuje się do realizmu bytowego i poznawczego, dlatego można uznać, że ujęcie to jest nadal aktualne.

W związku z tym, celem niniejszej publikacji jest przedstawienie w aspekcie teoretycznym wychowania człowieka w perspektywie personalizmu oraz przybliżenie koncepcji pedagogiki realistycznej o. Jacka Woronieckiego. Biorąc pod uwagę złożoność tego zagadnienia, zostały omówione tylko wybrane jego aspekty. W pierwszej kolejności przedstawiono antropologiczne podstawy wychowania ze szczególnym omówieniem uniwersalizmu i realizmu pedagogicznego. Następnie ukazano, jak rozumiał i definiował wychowanie o. Jacek Woroniecki, oraz omówiono jego koncepcję rozwoju człowieka - od osobowości do osobistości. Przedstawiono także wybrane działania, które zastosowane $\mathrm{w}$ procesie wychowania pomagają człowiekowi $\mathrm{w}$ dochodzeniu i osiąganiu doskonałości.

Słowa kluczowe: osobistość; osobowość; pedagogika realistyczna; personalizm; uniwersalizm pedagogiczny; wychowanie. 